\title{
Pola Asuh Permisif Ibu dan Perilaku Merokok Pada Remaja Laki-Laki di Sma Negeri 1 Semarapura
}

\author{
Ni Luh Putu Yuni Sanjiwani dan I Gusti Ayu Putu Wulan Budisetyani \\ Program Studi Psikologi, Fakultas Kedokteran, Universitas Udayana \\ abicksanji@yahoo.com
}

\begin{abstract}
Abstrak
Indonesia menduduki peringkat ke-4 jumlah perokok terbanyak di dunia yang tidak hanya terdiri dari orang dewasa namun juga remaja. Terdapat beberapa hal yang memengaruhi perilaku merokok pada remaja antara lain pola asuh orang tua, pengaruh teman sebaya, faktor kepribadian, dan juga pengaruh iklan. Pola asuh adalah aspek yang akan dikaji dalam penelitian ini, yang mana terdapat tiga macam pola asuh yaitu demokratis, otoriter, dan permisif. Pola asuh permisif merupakan salah satu bentuk pola asuh yang kiranya terkait dengan perilaku merokok. Pola asuh permisif memiliki karakteristik tidak membimbing anak, menyetujui segala tingkah laku anak, serta tidak menggunakan hukuman, sehingga membuat anak berani melakukan perilaku maladaptif seperti merokok. Mengingat prevalensi perilaku merokok di kalangan laki-laki lebih besar, peneliti ingin melihat apakah ada hubungan antara pola asuh permisif ibu dan perilaku merokok pada remaja laki-laki di SMA Negeri 1 Semarapura.

Subjek penelitian adalah 75 siswa laki-laki SMA Negeri 1 Semarapura. Metode penelitian menggunakan studi korelasi. Pengambilan data dilakukan menggunakan kuesioner. Kuesioner pola asuh permisif ibu memiliki 16 item sahih dengan koefisien reliabilitas 0,916 yang berarti kuesioner tersebut reliabel karena koefisien reliabilitasnya lebih besar dari standar minimal 0,600. Kuesioner perilaku merokok memiliki 20 item sahih dengan koefisien reliabilitas 0,906 yang berarti kuesioner tersebut reliabel karena koefisien reliabilitasnya lebih besar dari standar minimal 0,600. Hasil uji asumsi menunjukkan bahwa data memiliki persebaran normal dan linear. Uji linearitas antara pola asuh permisif ibu dan perilaku merokok memiliki signifikansi 0,000 yang berarti linear karena lebih rendah dari taraf signifikansi 0,05. Hasil penelitian menemukan hubungan yang signifikan antara pola asuh permisif ibu dan perilaku merokok dengan koefisien korelasi 0,493. Koefisien determinasi bernilai 0,243 yang menyatakan bahwa pola asuh permisif ibu berkontribusi terhadap perilaku merokok sebesar $24,3 \%$.
\end{abstract}

Kata kunci: pola asuh permisif, perilaku merokok, remaja laki-laki

\begin{abstract}
Indonesia placed the 4 th rank in the highest number of smokers in the world which consisted of not only adults but also adolescents. There are several things that influence adolescent smoking behavior, namely parenting style, peers, personality factors, and also advertisements. Parenting style which will be investigated in this research has three forms namely democratic, authoritarian, and permissive. Permissive parenting style is one form of parenting style which is presumably associated with smoking behavior. Permissive parenting style has characteristics as no child guiding, agreeing child's behavior, and do not use punishment, thus making the child feels brave in doing maladaptive behaviors such as smoking. Since the prevalence of smoking behavior among men is bigger, the researcher wanted to see whether there is a relationship between permissive parenting style of mother and smoking behavior of male adolescents in SMA Negeri 1 Semarapura.

Subjects in this research are 75 male students in SMA Negeri 1 Semarapura. Research method uses correlational study. Data are collected with questionnaires. Permissive parenting style of mother questionnaire has 16 valid items and its reliability coefficient is 0,916 which means the questionnaire is reliable since its reliability coefficient is higher than minimum standard 0,600. Smoking behavior questionnaire has 20 valid items and its reliability coefficient is 0,906 which means the questionnaire is reliable since its reliability coefficient is higher than minimum standard 0,600 . Result of assumption test shows data are normal and linear. Linearity test between permissive parenting style of mother and smoking behavior has significance level 0,000 which means linear since its significance level is lower than 0,05 . Result of this research finds positive significant relationship between permissive parenting style of mother and smoking behavior and its correlational coefficient is 0,493 . The value of coefficient of determination is 0,243 which shows permissive parenting style of mother has $24,3 \%$ contribution to smoking behavior.
\end{abstract}

Keywords: permissive parenting style, smoking behavior, male adolescents. 


\section{LATAR BELAKANG}

Salah satu kebiasaan masyarakat saat ini yang dapat ditemui hampir di setiap kalangan masyarakat adalah perilaku merokok. Rokok merupakan suatu hal yang tidak asing lagi di masyarakat. Orang-orang yang merokok mudah ditemui di berbagai lokasi, seperti di rumah, kantor, kafe, tempat-tempat umum, di dalam kendaraan, bahkan hingga di sekolahsekolah.

Indonesia menduduki peringkat ke-4 jumlah perokok terbanyak di dunia dengan jumlah sekitar 141 juta orang dengan korban 57 ribu perokok meninggal dan sekitar 500 ribu menderita berbagai penyakit. Diperkirakan konsumsi rokok Indonesia setiap tahun mencapai 199 milliar batang rokok atau berada di urutan ke-5 setelah Cina (1.979 miliar batang), Amerika Serikat (480 miliar batang), Jepang (230 miliar batang), serta Rusia (230 miliar batang) (Karyadi, 2008).

Menurut Sitepoe (2005), perilaku merokok adalah suatu perilaku yang melibatkan proses membakar tembakau yang kemudian dihisap asapnya, baik menggunakan rokok ataupun pipa. Perilaku merokok ternyata tidak hanya dijumpai pada kalangan orang dewasa, namun juga dapat ditemui pada kalangan remaja. Perilaku merokok pada remaja umumnya semakin lama akan semakin meningkat sesuai dengan tahap perkembangannya yang ditandai dengan meningkatnya frekuensi dan intensitas merokok (Hasnida dan Kemala, 2005).

Smet (1994) mengatakan bahwa usia pertama kali merokok pada umumnya berkisar antara 11-13 tahun. Data World Health Organization (WHO) juga semakin mempertegas bahwa jumlah perokok yang ada di dunia sebanyak 30\% adalah kaum remaja (Komalasari dan Helmi, 2000). Tandra (dalam Hasnida dan Kemala, 2005) menyatakan penelitian di Jakarta menunjukkan bahwa 64,8\% laki-laki dengan usia di atas 13 tahun adalah perokok. Survei sosial ekonomi oleh Badan Pusat Statistik pada tahun 2001 dan 2004 menunjukkan terjadi peningkatan prevalensi anak-anak usia 15-19 tahun yang merokok. Pada tahun 2001, jumlah remaja yang merokok adalah sebesar $12,7 \%$ dan pada tahun 2004 meningkat menjadi $17,3 \%$. Berdasarkan data Global Youth Tobacco Survey tahun 2006 yang diselenggarakan oleh Badan Kesehatan Dunia, terbukti jika 24,5\% anak laki-laki dan 2,3\% anak perempuan berusia 13-15 tahun di Indonesia adalah perokok, di mana 3,2\% dari jumlah tersebut telah berada dalam kondisi ketagihan atau kecanduan (Rohman, 2012). Data terbaru berdasarkan hasil survei yang dilakukan oleh Lembaga Modernisator dan Fakultas Ekonomi Universitas Trisakti menunjukkan jika 31,3\% pelajar menjadi perokok, dimana 20,6\% diantaranya merupakan perokok aktif dan 10,7\% mengaku pernah merokok (Kompas, 2013).

Berdasarkan jenis kelamin, perokok laki-laki jauh lebih tinggi dibandingkan perempuan dimana jika diuraikan menurut umur, prevalensi perokok laki-laki paling tinggi pada umur 15-19 tahun. Sirait dkk. (dalam Hasnida dan Kemala, 2005) menyatakan remaja laki-laki pada umumnya mengkonsumsi rokok $11-20$ batang per hari $(49,8 \%)$ dan yang mengkonsumsi lebih dari 20 batang per hari sebesar 5,6\%. Yayasan Kanker Indonesia (YKI) menemukan 27,1\% dari 1.961 subjek pelajar laki-laki SMA/SMK, sudah mulai atau bahkan terbiasa merokok, umumnya siswa kelas satu menghisap satu sampai empat batang per hari, sementara siswa kelas tiga mengonsumsi rokok lebih dari sepuluh batang per hari (Amelia, 2009).

Menurut Murtiyani (2011), masa remaja merupakan masa yang rentan bagi seseorang untuk terlibat dalam perilaku menyimpang seperti merokok. Seorang remaja memilih untuk merokok erat kaitannya dengan belum matangnya mental seorang remaja. Seorang remaja sudah tidak lagi dapat dikatakan sebagai kanak-kanak, namun masih belum cukup matang untuk dikatakan dewasa sehingga masih sering gagal untuk mempertimbangkan dampak dari perilakunya sendiri. Remaja juga sedang mencari pola hidup yang paling sesuai baginya dan ini pun sering dilakukan melalui metode cobacoba, yang kadang kala berdampak negatif bagi dirinya sendiri dan orang lain seperti merokok. Namun remaja kerap kali mengabaikan dampaknya karena remaja masih dalam rangka mencari identitas diri dan tidak ragu untuk mencoba sesuatu yang baru meski berbahaya dalam rangka meningkatkan status sosial di lingkungan pergaulan.

Sejalan dengan pendapat tersebut, Erikson (dalam Fagan, 2006) menyatakan bahwa masa remaja merupakan masa yang rentan pada krisis aspek psikososial. Krisis aspek psikososial pada remaja merupakan krisis identitas yang berbentrokan dengan kebingungan. Krisis aspek psikososial ini terjadi karena remaja sedang berada dalam upaya mencari jati diri yang dibarengi ketidaksesuaian antara perkembangan psikis dan sosial. Untuk mengatasi tekanan yang diakibatkan krisis tersebut, remaja melakukan perilaku merokok sebagai cara mengatasi atau hanya sekedar mencoba-coba sesuatu yang baru dalam rangka menemukan jati dirinya. Perilaku merokok merupakan perilaku yang dapat dilakukan remaja dalam upaya meneguhkan identitas dirinya.

Di samping itu, masa remaja merupakan masa peralihan yang mana remaja menjadi labil dan mudah terpengaruh. Dalam konteks ini, labil dan mudah terpengaruh terkait dengan perilaku remaja yang mudah berubah dan kerentanan remaja untuk dipengaruhi oleh lingkungan sekitarnya. Dalam kondisi yang belum pasti inilah remaja rentan mengalami permasalahan dan berperilaku negatif karena masih labil dan emosinya belum terbentuk secara matang, salah satunya adalah merokok (Karyadi, 2008). Ada banyak alasan yang melatarbelakangi perilaku merokok pada remaja, antara lain mencontoh orang tua, mencontoh rekan sebaya, dan juga pola asuh orang tua (Komalasari \& Helmi, 
2000). Pola asuh ini patut diperhatikan karena bagaimana orang tua mengasuh anak akan memiliki peran yang sangat penting dalam perkembangan, baik itu perkembangan fisik, mental, emosi, maupun kepribadian, dari anak itu lahir hingga pada masa ia benar-benar melepaskan diri dari orang tua.

Hetherington dan Porke (1999) menyatakan bahwa pola asuh merupakan proses interaksi total antara orang tua dengan anak, meliputi proses pemeliharaan, perlindungan, dan pengajaran bagi anak. Pola asuh yang diterapkan orang tua akan sangat menentukan bagaimana perilaku anak nantinya dan apakah anak akan sanggup berperilaku sesuai dengan norma yang ada dalam masyarakat tanpa merugikan dirinya sendiri atau orang lain. Hal tersebut terjadi karena dalam proses pengasuhan, anak akan mencontoh orang tua sekaligus memperoleh gambaran mengenai apa yang boleh dan tidak boleh dilakukan dari batasan yang diterapkan oleh orang tua pada anak.

Pendapat tersebut juga didukung pendapat Atkinson, Atkinson, dan Hilgard (1983) yang menyatakan bahwa dalam masa remaja, nilai dan standar moral orang tua dianggap penting oleh remaja. Remaja yang sedang mencari identitas diri memutuskan apa yang penting dan patut dikerjakan salah satunya dengan mencontoh nilai dari orang tua. Jika orang tua tidak menerapkan nilai-nilai tertentu pada anak, maka besar kemungkinan anak akan berlaku seenaknya.

Baumrind (dalam Huver dkk, 2010) mengemukakan empat dimensi pola asuh, yaitu kendali orang tua, kejelasan komunikasi orang tua dengan anak, tuntutan kedewasaan, dan kasih sayang. Kendali orang tua terkait dengan segala perilaku yang merujuk pada upaya orang tua dalam menerapkan kedisiplinan pada anak sesuai dengan patokan tingkah laku yang sudah dibuat sebelumnya. Kejelasan komunikasi orang tua dengan anak merujuk pada kesadaran orang tua untuk mendengarkan atau menampung pendapat, keinginan atau keluhan anak, dan juga kesadaran orang tua dalam memberikan hukuman kepada anak bila diperlukan. Tuntutan kedewasaan merujuk pada dukungan prestasi, sosial, dan emosi dari orang tua terhadap anak. Kasih merujuk pada kehangatan dan keterlibatan orang tua dalam upaya memperhatikan kesejahteraan dan kebahagiaan anak.

Pola asuh yang kurang memiliki kendali orang tua dan kurangnya aspek pemberian hukuman dalam kejelasan komunikasi orang tua pada anak adalah pola asuh permisif. Menurut Hurlock (1976), pola asuh permisif adalah pola asuh orang tua yang dicirikan dengan tidak membimbing anak dan menyetujui segala tingkah laku anak termasuk keinginankeinginan yang sifatnya segera dan tidak menggunakan hukuman. Pola asuh ini ditandai dengan adanya kebebasan tanpa batas pada anaknya untuk berperilaku sesuai dengan keinginannya sendiri dan orang tua tidak pernah memberi aturan dan pengarahan kepada anak. Semua keputusan diserahkan kepada anak tanpa pertimbangan dari orang tua.
Anak tidak tahu apakah perilakunya benar atau salah karena orang tua tidak pernah membenarkan atau menyalahkan anak, sehingga anak akan berperilaku sesuai dengan keinginannya sendiri, tidak peduli apakah hal itu sesuai dengan norma masyarakat atau tidak. Pola asuh permisif membuat hubungan anak-anak dengan orang tua penuh dengan kasih sayang, tapi menjadikan anak agresif dan suka menuruti kata hatinya. Secara lebih luas, kelemahan orang tua dan tidak konsistennya disiplin yang diterapkan membuat anak-anak tidak terkendali, tidak patuh, dan akan bertingkah laku agresif di luar lingkungan keluarga. Kurangnya kendali orang tua dan pemberian hukuman pada anak dapat mendorong seorang anak untuk terlibat dan melanjutkan perilaku tertentu, seperti merokok.

Meski semua orang tahu akan bahaya yang ditimbulkan oleh rokok, perilaku merokok tidak akan pernah surut dan tampaknya hal itu masih dapat diterima begitu saja oleh masyarakat. Hal ini tampak dalam kehidupan sehari-hari, baik di rumah, di jalan-jalan, di angkutan umum, maupun tempat umum lainnya, hampir setiap saat dapat dijumpai orang-orang yang sedang merokok. Hal yang lebih memprihatinkan lagi adalah kebanyakan dari mereka merupakan remaja laki-laki yang belum genap berusia 18 tahun.

Kondisi tersebut yang melatarbelakangi peneliti untuk melakukan penelitian mengenai pengaruh pola asuh permisif ibu terhadap perilaku merokok pada remaja laki-laki di SMA Negeri 1 Semarapura. Pola asuh permisif ini difokuskan pada pola asuh ibu, karena sebagaimana yang dinyatakan oleh Paterson (1993), remaja laki-laki akan cenderung bergantung pada ibu untuk masalah dukungan dan kedekatan daripada dengan ayah. Remaja laki-laki juga menganggap figur ibu lebih responsif dan bertanggung jawab daripada figur ayah. Hal ini terjadi karena remaja laki-laki bergantung pada sosok ibu untuk memperoleh dukungan emosional, sementara ketergantungan pada sosok ayah umumnya bersifat finansial belaka. Ibu juga dipandang lebih peka dan suportif secara emosional terhadap remaja laki-laki. Ibu menghargai individualitas, kerapuhan, dan sensitifitas remaja laki-laki sekaligus kekuatannya. Hal ini membuat remaja laki-laki lebih berani berekspresi dan bergantung pada sosok ibu, karena ibu adalah figur orang tua yang memberikan kenyamanan dan kepekaan emosional (Lombardi, 2012). Rosentahl dan Kobak (2010) menyatakan bahwa ibu ditempatkan dalam posisi teratas figur kelekatan utama remaja terkait dengan teori persepsi penerimaan orang tua. Preferensi remaja terkait orang tua sebagai figur kelekatan utama dipengaruhi persepsi mengenai ketersediaan orang tua, frekuensi kontak, dan responsivitas. Ibu merupakan figur yang dipandang lebih dekat, responsif, dan mudah dicari oleh anak, sehingga ditempatkan sebagai figur kelekatan utama 
Tidak hanya itu, Eliasa (2011) menyatakan ibu menempati peringkat pertama pada pengasuhan anak, yang akhirnya menjadikan ibu sebagai figur kelekatan utama. Setelah dilakukan penelitian, diharapkan nantinya hasil penelitian ini dapat menjadi sumber bacaan dan pertimbangan bagi orang tua khususnya ibu dalam mengasuh anak-anaknya agar tidak melakukan perilaku negatif khususnya merokok. Hal tersebut juga didukung oleh hasil penelitian Rosenthal dan Kobak (2010) yang menyatakan bahwa baik remaja laki-laki dan perempuan yang duduk di bangku sekolah menengah atas menempatkan figur ayah di bawah figur ibu, teman sebaya, dan pasangan dalam hirarki kelekatan utama.

\section{METODE}

\section{Hipotesis}

Berdasarkan apa yang sudah diuraikan di latar belakang, peneliti mengajukan hipotesis nol dan hipotesis alternatif yaitu:

Ho : $\beta 1=0$, artinya tidak ada hubungan yang signifikan antara pola asuh permisif ibu dengan perilaku merokok remaja lakilaki di SMA Negeri 1 Semarapura.

HA : $\beta 1 \neq 0$, artinya ada hubungan yang signifikan antara pola asuh permisif ibu dengan perilaku merokok remaja laki-laki di SMA Negeri 1 Semarapura.

\section{Variabel dan definisi operasional}

Terdapat dua jenis variabel dalam penelitian ini, yaitu variabel bebas dan variabel tergantung. Variabel bebas dalam penelitian ini adalah pola asuh permisif ibu. Variabel tergantung dalam penelitian ini adalah perilaku merokok. Berikut ini adalah definisi operasional masing-masing variabel:

1. Definisi operasional pola asuh permisif ibu

Pola asuh permisif ibu adalah pola asuh ibu yang tidak membimbing anak dan menyetujui segala tingkah laku anak termasuk keinginan-keinginan yang sifatnya segera dan tidak menggunakan hukuman. Hal ini diukur dari persepsi subjek apakah ibu subjek memberi kebebasan tanpa batas pada anaknya untuk berperilaku sesuai dengan keinginannya sendiri, ibu tidak pernah memberi aturan dan pengarahan kepada anak, dan semua keputusan diserahkan kepada anak tanpa pertimbangan dari ibu. Pola asuh permisif ibu akan diukur dengan kuesioner yang terdiri dari tiga aspek, menurut Hurlock (1976), yaitu tidak membimbing anak, menyetujui segala tingkah laku anak, dan tidak menggunakan hukuman. Kuesioner disusun sendiri oleh peneliti dan menggunakan empat pilihan jawaban untuk tiap pernyataan yakni sangat setuju, setuju, tidak setuju, dan sangat tidak setuju. Untuk pernyataan favorable, jawaban sangat setuju (SS) diberi nilai 4, setuju (S) diberi nilai 3, tidak setuju (TS) diberi nilai 2, dan sangat tidak setuju (STS) diberi nilai 1. Untuk pernyataan unfavorable, jawaban sangat setuju (SS) diberi nilai 1, setuju (S) diberi nilai 2, tidak setuju (TS) diberi nilai 3, sangat tidak setuju (STS) diberi nilai 4.

2. Definisi operasional perilaku merokok

Perilaku merokok adalah suatu aktivitas membakar dan menghisap tembakau kemudian mengeluarkan asapnya yang dapat terhisap oleh orang di sekitarnya. Perilaku merokok akan diukur dengan empat aspek dari Aritonang (dalam Nasution, 2007) yaitu fungsi merokok, intensitas merokok, tempat merokok, dan waktu merokok. Kuesioner disusun sendiri oleh peneliti dengan empat pilihan jawaban yaitu sangat sering, sering, jarang, dan tidak pernah. Jika subjek menjawab pilihan sangat sering skor 4, sering skor 3, jarang skor 2, dan tidak pernah skor 1 .

\section{Subjek}

Subjek dipilih melalui teknik total sampling dari populasi berupa siswa laki-laki SMA Negeri 1 Semarapura yang memiliki ibu dengan tipe pola asuh permisif. Total sampling merupakan teknik pengambilan sampel dimana sampel sama dengan populasi (Sugiyono, 2007). Dengan kata lain, teknik total sampling yang melibatkan semua angota populasi sebagai sampel. Dalam penelitian ini, terdapat kriteria sampel yaitu siswa terdaftar sebagai siswa di SMA Negeri 1 Semarapura Tahun Ajaran 2012/2013 dan berusia 14-18 tahun, berjenis kelamin laki-laki, memiliki ibu dengan tipe pola asuh permisif, aktif mengikuti pendidikan di SMA Negeri 1 Semarapura, dan bersedia menjadi subjek. Agar dapat mengetahui pola asuh yang digunakan oleh ibu siswa laki-laki SMA Negeri 1 Semarapura, peneliti melakukan klasifikasi jenis pola asuh dari kuesioner pola asuh yang disebarkan pada tahap uji coba. Untuk menentukan besarnya sampel, digunakan patokan jumlah sampel minimum berdasarkan atas jenis penelitian yang dibuat oleh Fraenkel dan Wallen (1993):

1. Penelitian deskriptif membutuhkan sampel minimal sebanyak 100 orang

2. Penelitian korelasional membutuhkan sampel minimal sebanyak 50 orang.

3. Penelitian kausal komparatif membutuhkan sampel minimal sebanyak 30 orang untuk setiap kelompok sampel yang diteliti.

4. Penelitian eksperimental membutuhkan sampel minimal sebanyak 30 orang untuk setiap kelompok sampel yang diteliti.

Hasil tryout menunjukkan bahwa jumlah siswa lakilaki SMA Negeri 1 Semarapura yang memiliki ibu dengan tipe pola asuh permisif adalah sebanyak 75 orang. Seluruhnya akan digunakan sebagai sampel dalam penelitian ini sesuai kaidah teknik total sampling. Jumlah tersebut telah melebihi jumlah patokan pengambilan sampel minimal untuk penelitian korelasional dari Fraenkel dan Wallen (1993) yaitu 50 orang. 


\section{Tempat penelitian}

Penelitian ini dilangsungkan di SMA Negeri 1 Semarapura, pada bulan Januari 2013.

\section{Alat ukur}

Alat pengumpulan data yang digunakan dalam penelitian ini adalah kuesioner. Dalam fase tryout, peneliti menggunakan dua kuesioner yaitu kuesioner pola asuh yang mencakup tiga jenis pola asuh yaitu pola asuh permisif, pola asuh otoriter, dan pola asuh demokratis dengan aspek dari Hurlock (1976). Kuesioner tersebut digunakan untuk memilah siapa saja siswa yang memiliki ibu dengan pola asuh permisif. Selain itu digunakan pula kuesioner perilaku merokok dengan aspek dari Aritonang (dalam Nasution, 2007).

Pada fase tryout, peneliti menyebarkan 156 kuesioner pada siswa laki-laki SMA Negeri 1 Semarapura. Selain untuk memilah siapa saja siswa yang memiliki ibu dengan pola asuh permisif, uji coba juga dilakukan untuk menguji validitas dan reliabilitas alat ukur. Uji validitas dapat dilakukan dengan mengkorelasikan antara skor item instrumen dalam suatu faktor. Jika nilai yang diperoleh positif dan besarnya $0,3 \mathrm{ke}$ atas, maka faktor tersebut merupakan construct dalam penelitian dijelaskan suatu derajat ketepatan alat ukur penelitian tentang hari atau sebenarnya diukur (Sugiyono, 2007). Menurut Nunnaly (1978) dan Ghozali (2002), pengujian reliabilitas dilakukan dengan menggunakan teknik statistik Crobach's alpha, yaitu instrumen dikatakan reliabel untuk mengukur bila memiliki nilai alpha lebih besar atau sama dengan 0,6 .

Setelah melalui tahap pengujian validitas dan reliabilitas tersebut, ditemukan bahwa kuesioner pola asuh permisif memiliki 16 item sahih dengan koefisien reliabilitas 0,916 dan kuesioner perilaku merokok memiliki 20 item sahih dengan koefisien reliabilitas 0,906 . Selain itu, ditemukan pula bahwa terdapat 75 siswa yang memiliki ibu dengan pola asuh permisif, 50 siswa yang memiliki ibu dengan pola asuh demokratis, dan 31 siswa yang memiliki ibu dengan pola asuh otoriter. 75 orang siswa yang memiliki ibu dengan pola asuh permisif akan sampel dalam penelitian ini sesuai kaidah total sampling yang mempergunakan seluruh anggota populasi sebagai sampel.

\section{Metode pengumpulan data}

Pengumpulan data akan menentukan kualitas data yang digunakan untuk menentukan hasil penelitian nantinya, sehingga perlu dilakukan dengan baik. Dalam penelitian ini, pengumpulan data dilakukan dengan cara melakukan pengukuran terhadap dua variabel penelitian, yaitu pola asuh permisif ibu dan perilaku merokok. Seluruh variabel diukur dengan kuesioner. Data diperoleh dengan mengambil seluruh anggota populasi sebesar 75 siswa SMA Negeri 1 Semarapura yang memiliki ibu dengan tipe pola asuh permisif (yang dipilah melalui proses tryout) sebagai sampel. Sebelum mengadakan uji coba alat ukur, peneliti mendatangi SMA Negeri 1 Semarapura dengan membawa surat permohonan pengambilan data skripsi. Ketika sudah disetujui, barulah peneliti menyebarkan kuesioner. Dalam fase tryout, peneliti menyebarkan kuesioner yang memuat tiga jenis pola asuh dan kuesioner perilaku merokok. Pada fase penelitian, peneliti menyebarkan kuesioner yang hanya memuat pola asuh permisif saja dan perilaku merokok. Begitu seluruh kuesioner terkumpul, peneliti mengambil kembali kuesioner dan memasukkan seluruh data ke dalam program SPSS 13 untuk diolah.

\section{Teknik analisis data}

Secara spesifik, penelitian ini merupakan bentuk studi korelasional. Analisis dilakukan dengan memakai program bantu SPSS dengan teknik korelasi Product Moment Pearson yang melihat besar signifikansi (p) dan besar korelasi (r). Jika $\mathrm{p}<0,05$, hubungan dinyatakan signifikan dan begitu juga sebaliknya. Menggunakan nilai $r$, dengan nilai $r$ terbesar adalah +1 dan $r$ terkecil adalah $-1 . r=+1$ menunjukkan hubungan positif sempurna, sedangkan $r=-1$ menunjukkan hubungan negatif sempurna. Nilai $r$ tidak mempunyai satuan atau dimensi. Tanda (+) atau (-) hanya menunjukkan arah hubungan. Intrepretasi nilai $\mathrm{r}$ adalah sebagai berikut (Boediono \& Koster, 2004):

\begin{tabular}{|c|c|}
\hline Koefisien Korelasi & Kategorisasi \\
\hline $0,90<\mathrm{r}<1,00$ atau $-1,00<\mathrm{r}<-0,90$ & Sangat kuat \\
\hline $0,70<\mathrm{r}<0,90$ atau $-0,90<\mathrm{r}<-0,70$ & Kuat \\
\hline $0,50<\mathrm{r}<0,70$ atau $-0,70<\mathrm{r}<-0,50$ & Moderat \\
\hline $0,30<\mathrm{r}<0,50$ atau $-0,50<\mathrm{r}<-0,30$ & Lemah \\
\hline $0,00<\mathrm{r}<0,30$ atau $-0,30<\mathrm{r}<0,00$ & Sangat lemah \\
\hline
\end{tabular}

\section{Hasil Penelitian}

Sebelum melihat apakah terdapat hubungan antara variabelvariabel yang ingin diteliti, peneliti melakukan uji asumsi yang meliputi uji normalitas dan uji linearitas untuk memastikan bahwa data memang layak dan bisa digunakan dalam penelitian.

Untuk melihat apakah data pola asuh permisif ibu dan perilaku merokok telah sesuai dengan kurva normal, maka dilakukan uji normalitas dengan Kolmogorov-Smirnov. Bila taraf signifikansi lebih besar dari 0,05, maka data dinyatakan normal. Bila taraf signifikansi kurang dari 0,05, maka data 
dinyatakan berbeda dengan kurva normal dan harus diuji dengan analisis nonparametrik (Sugiyono, 2011). Berikut adalah hasil uji normalitas variabel pola asuh permisif ibu dan perilaku merokok.

Tabel 1

Hasil Uji Normalitas

\begin{tabular}{|c|c|c|}
\hline Kolmogorov-Smirnov & Pola Asuh Permisif & Perilaku Merokok \\
\hline Asymp. Significant (2-tailed) & 0,128 & 0,899 \\
\hline
\end{tabular}

Sebaran data pada variabel pola asuh permisif ibu memiliki nilai signifikansi dengan probabilitas (p) sebesar 0,128 atau memiliki probabilitas di atas $0,05(\mathrm{p}>0,05)$. Hal ini menunjukkan bahwa sebaran data pada variabel pola asuh permisif ibu bersifat normal. Dengan kata lain, sebaran data telah sesuai dengan kurva normal. Sebaran data pada variabel perilaku merokok memiliki nilai signifikansi dengan probabilitas sebesar 0,899 atau memiliki probabilitas di atas $0,05$ ( $\mathrm{p}>0,05)$. Hal ini menunjukkan bahwa sebaran data pada variabel perilaku merokok bersifat normal. Dengan kata lain, sebaran data telah sesuai dengan kurva normal.

Selain itu, dilakukan pula uji linearitas untuk melihat apakah hubungan antara satu variabel dependen dengan variabel independen bersifat linear. Asumsi linearitas dapat diuji menggunakan compare means dengan SPSS. Asumsi linearitas menyatakan bahwa hubungan antara variabel terikat dan bebas harus berbentuk garis lurus. Apabila nilai signifikansi uji linearitas lebih kecil dari 0,05, data dinyatakan linear. Apabila nilai signifikansi uji linearitas lebih besar dari 0,05 , data dinyatakan tidak linear dan harus dianalisis dengan analisis nonparametrik. Asumsi linearitas dapat diuji dengan menggunakan compare means - test for linearity pada program SPSS. Berikut adalah hasil uji linearitas pola asuh permisif ibu dan perilaku merokok.

Tabel 2

Hasil Uji Linearitas Pola Asuh Permisif Ibu dan Perilaku Merokok

\begin{tabular}{|l|l|l|c|c|}
\hline \multicolumn{2}{|c|}{ BFI*SAM } & F & Signifikansi \\
\hline & $\begin{array}{l}\text { Between } \\
\text { Groups }\end{array}$ & (Combined) & 2,126 & 0,011 \\
\hline \multirow{2}{*}{} & Linearity & 26,973 & 0,000 \\
\cline { 2 - 4 } & Deviation from linearity & 1,349 & 0,182 \\
\hline
\end{tabular}

Hasil pengujian menunjukkan bahwa pola asuh permisif ibu dan perilaku merokok adalah linear karena memiliki probabilitas (p) sebesar 0,000 atau memiliki taraf signifikansi untuk linearitas lebih kecil dari 0,05 ( $\mathrm{p}<0,05)$ sehingga hubungan pola asuh permisif ibu dan perilaku merokok telah membentuk garis yang sejajar atau lurus.

Berdasarkan uji normalitas dan uji linearitas yang telah dilakukan diperoleh hasil bahwa data penelitian bersifat normal dan linear sehingga korelasi Pearson's Product Moment dapat digunakan untuk menguji hipotesis. Berikut adalah hasil korelasi Pearson's Product Moment:
Tabel 3

Hasil Uji Korelasi Pearson's Product Moment

\begin{tabular}{|l|l|l|l|}
\hline & & totalPA & total \\
\hline totalPA & $\begin{array}{l}\text { Pearson Correlation } \\
\text { Sig. (1-tailed) }\end{array}$ & 1 & $.493^{* *}$ \\
& $\mathrm{~N}$ & 75 & .000 \\
& & 75 \\
\hline total & $\begin{array}{l}\text { Pearson Correlation } \\
\text { Sig. (1-tailed) } \\
\text { N }\end{array}$ & $\begin{array}{l}.493^{*} \\
.000 \\
75\end{array}$ & 1 \\
& $75 \%$ Correlation is significant at the 0.01 level (1-tailed). & 75 \\
\hline
\end{tabular}

Dari tabel hasil uji korelasi di atas, dapat diketahui bahwa terdapat hubungan yang signifikan antara pola asuh permisif ibu dan perilaku merokok. Nilai $R$ sebesar 0,493 berada di rentang 0,41-0,60 sehingga hubungan keduanya dinyatakan lemah menurut rentang dari Boediono dan Koster (2004). Maksud dari hubungan lemah ini adalah perilaku merokok terikat secara lemah dengan pola asuh permisif ibu. Perubahan skor pada pola asuh permisif ibu hanya menimbulkan perubahan yang kecil pada skor perilaku merokok. Nilai positif pada koefisien korelasi menunjukkan bahwa hubungan pola asuh permisif ibu dan perilaku merokok bersifat positif di mana peningkatan skor pola asuh permisif ibu akan meningkatkan skor perilaku merokok.

Untuk melihat kontribusi pola asuh permisif ibu terhadap perilaku merokok, perlu ditinjau koefisien determinasi yang dapat dihitung dari mengkuadratkan nilai koefisien korelasi. Koefisien determinasi yang didapat ialah sebesar 0,243, yang mengandung arti bahwa pola asuh permisif ibu berkontribusi terhadap perilaku merokok sebesar $24,3 \%$ dan sisanya sebesar $75,7 \%$ dapat dijelaskan oleh variabel lain yang tidak diteliti dalam penelitian ini.

Selain itu, dilakukan kategorisasi pada variabel perilaku merokok sesuai dengan aspek-aspeknya. Perilaku merokok terdiri atas empat aspek, yaitu fungsi merokok, tempat merokok, waktu merokok, dan intensitas merokok. Untuk mengetahui bagaimana perilaku merokok pada remaja laki-laki SMA Negeri 1 Semarapura, dilakukan kategorisasi dengan cara deskriptif yang menghasilkan data sebagai berikut:

\begin{tabular}{|l|l|c|}
\hline Aspek & Indikator & Jumlah \\
\hline \multirow{5}{*}{ Fungsi merokok } & Menambah kenikmatan & 21 \\
\cline { 2 - 3 } & Menyenangkan perasaan & 23 \\
\cline { 2 - 3 } & Mengurangi perasaan cemas, marah dan gelisah & 43 \\
\cline { 2 - 3 } & Ketagihan & 35 \\
\cline { 2 - 3 } & Kebiasaan & 37 \\
\hline \multirow{5}{*}{ Tempat merokok } & Sekolah & 7 \\
\cline { 2 - 3 } & Kendaraan umum & 3 \\
\cline { 2 - 3 } & Restoran & 15 \\
\cline { 2 - 3 } & Smoking area & 17 \\
\cline { 2 - 3 } & Stasiun & 1 \\
\cline { 2 - 3 } & Mall & 14 \\
\cline { 2 - 3 } & Kamar pribadi & 30 \\
\cline { 2 - 3 } & Toilet & 26 \\
\hline & Setiap hari & 7 \\
\cline { 2 - 3 } & baru bangun tidur & 2 \\
\cline { 2 - 3 } & Setelah sarapan & 10 \\
\cline { 2 - 3 } & Saat buang air besar & 2 \\
\cline { 2 - 3 } & Saat jam istirahat pelajaran sekolah & 3 \\
\hline
\end{tabular}




\begin{tabular}{|l|l|c|}
\hline \multirow{4}{*}{ Setelah makan siang } & 15 \\
\cline { 2 - 3 } & Setlah makan malam & 17 \\
\cline { 2 - 3 } Intensitas merokok & Menjelang tidur malam & 30 \\
\cline { 2 - 3 } & 1-4 batang per hari & 21 \\
\cline { 2 - 3 } & 4-15 batang per hari & 37 \\
\cline { 2 - 3 } & lebih dari 15 batang per hari & 5 \\
\hline
\end{tabular}

Berdasarkan fungsi merokok, siswa laki-laki SMA Negeri 1 Semarapura memilih merokok untuk menambah kenikmatan ada 21 orang, menyenangkan perasaan ada 23 orang, mengurangi perasaan cemas, marah, dan gelisah ada 43 orang, ketagihan ada 35 orang, yang kebiasaan ada 37 orang. Dapat dilihat bahwa rata-rata siswa SMA Negeri 1 Semarapura merokok untuk mengurangi perasaan cemas, marah, dan gelisah berdasarkan atas fungsi merokok.

Berdasarkan tempat merokok, siswa laki-laki SMA Negeri 1 Semarapura yang merokok di sekolah ada 7 orang, di kendaraan umum 3 orang, di restoran 15 orang, di smoking area 17 orang, di stasiun 1 orang, di mall 14 orang, di kamar pribadi 30 orang, dan di toilet 3 orang.

Berdasarkan waktu merokok, siswa laki-laki SMA Negeri 1 Semarapura yang merokok setiap hari ada 26 orang, merokok saat baru bangun tidur ada 7 orang, setelah sarapan ada 3 orang, saat buang air besar ada 2 orang, saat jam istirahat pelajaran sekolah ada 10 orang, setelah makan siang ada 15 orang, setelah makan malam ada 17 orang, dan menjelang tidur malam ada 30 orang.

Berdasarkan intensitas merokok, siswa laki-laki SMA Negeri 1 Semarapura yang merokok 1-4 batang per hari ada 21 orang, 4-15 batang per hari ada 37 orang, dan lebih dari 15 batang per hari ada 5 orang.

Dari sana, dapat ditarik gambaran bahwa rata-rata siswa laki-laki SMA Negeri 1 Semarapura merokok untuk mengurangi perasaan cemas, marah dan gelisah berdasarkan fungsi merokok, merokok di kamar pribadi berdasarkan tempat merokok, merokok menjelang tidur malam berdasarkan waktu merokok, dan merokok 4-15 batang sehari berdasarkan intensitas merokok.

\section{PEMBAHASAN}

Hipotesis dalam penelitian berbunyi "ada hubungan yang signifikan antara pola asuh permisif ibu dengan perilaku merokok remaja laki-laki SMA Negeri 1 Semarapura". Hipotesis tersebut telah diuji dengan analisis statistik korelasi Pearson's Product Moment, yang mana menunjukkan adanya hubungan positif yang signifikan antara pola asuh permisif ibu dan perilaku merokok remaja laki-laki SMA Negeri 1 Semarapura. Kekuatan hubungan antara pola asuh permisif ibu dan perilaku merokok remaja laki-laki SMA Negeri 1 Semarapura adalah 0,493 yang mana tergolong hubungan yang lemah menurut rentang yang diajukan Boediono dan Koster (2004). Di samping itu, peneliti juga melihat nilai koefisien determinasi agar diketahui berapa sumbangan pola asuh permisif ibu terhadap perilaku merokok remaja laki-laki SMA Negeri 1 Semarapura. Nilai koefisien determinasi sebesar 0,243 menunjukkan bahwa pola asuh permisif ibu memiliki sumbangan sebesar $24,3 \%$ terhadap perilaku merokok dan sisa sebesar $75,7 \%$ ditentukan variabel lain.

Theodorus (dalam Komalasari dan Helmi, 2000) menyatakan bahwa anak tidak serta merta merokok karena mencontoh perilaku merokok orang lain. Anak yang bersangkutan merokok karena memperoleh penguatan dan pengukuhan atas perilaku merokoknya melalui ketiadaan hukuman untuk perilaku yang bersangkutan. Hal tersebut sesuai dengan teori belajar yang menyatakan bahwa sebuah perilaku akan bertahan apabila mendapat penguatan (Taylor, Peplau, \& Sears, 2009). Ketiadaan teguran dan hukuman dari orang tua terkait dengan perilaku merokok anak akan dianggap sebagai suatu bentuk pengukuhan atas perilaku merokoknya sehingga perilaku merokok tersebut tetap dijalankan. Hasil riset yang diperoleh peneliti sejalan dengan pendapat Smet (1994) yang menyatakan bahwa sikap permisif orang tua terhadap perilaku merokok merupakan prediktor yang cukup baik terhadap perilaku merokok remaja karena sikap permisif tersebut diterjemahkan sebagai adanya izin untuk merokok oleh remaja.

Sejalan dengan hasil penelitian ini, pola asuh permisif ibu berhubungan lemah dengan perilaku merokok dengan besar korelasi 0,493 karena pada usia remaja, faktor terbesar yang menentukan perilaku remaja adalah teman sebaya. Nilai-nilai kelompok sebaya dipandang penting oleh remaja dan ketergantungan pada nilai-nilai orang tua mulai melemah (Atkinson, Atkinson, \& Hilgard, 1983).

Pola asuh permisif ibu berhubungan positif signifikan dengan perilaku merokok. Aspek-aspek pola asuh permisif sendiri yaitu tidak membimbing anak, menyetujui segala tingkah laku anak, serta tidak menggunakan hukuman (Hurlock, 1976) yang mendorong terciptanya hubungan tersebut. Tidak adanya bimbingan pada anak membuat anak tidak memiliki patokan pasti dalam bersikap sehingga akhirnya melakukan perilaku seperti merokok. Anak akan menganggap bahwa perilaku merokok bukanlah perilaku negatif karena kurangnya bimbingan akan dampak buruk perilaku merokok. Ibu dengan pola asuh permisif juga umumnya menyetujui segala tingkah laku anak, termasuk perilaku merokok yang sudah terbukti dapat berakibat negatif pada kesehatan. Ibu dengan pola asuh permisif juga enggan menggunakan hukuman sehingga anak terbiasa untuk bertingkah sesuai keinginannya sendiri. Tidak adanya teguran akan perilaku merokok anak membuat anak berpandangan bahwa perilaku merokok tersebut boleh-boleh saja dilakukan dan dapat ditolerir dengan mudah.

Dari hasil kategorisasi deskriptif, berdasarkan fungsi merokok, siswa laki-laki SMA Negeri 1 Semarapura yang merokok untuk menambah kenikmatan ada 21 orang, yang 
menyenangkan perasaan ada 23 orang, yang mengurangi perasaan cemas, marah, dan gelisah ada 43 orang, yang ketagihan ada 35 orang, dan yang kebiasaan ada 37 orang. Dapat dilihat bahwa rata-rata siswa SMA Negeri 1 Semarapura merokok untuk mengurangi perasaan cemas, marah, dan gelisah berdasarkan atas fungsi merokok.

Berdasarkan tempat merokok, siswa laki-laki SMA Negeri 1 Semarapura yang merokok di sekolah ada 7 orang, di kendaraan umum 3 orang, di restoran 15 orang, di smoking area 17 orang, di stasiun 1 orang, di mall 14 orang, di kamar pribadi 30 orang, dan di toilet 3 orang.

Berdasarkan waktu merokok, siswa laki-laki SMA Negeri 1 Semarapura yang merokok setiap hari ada 26 orang, merokok saat baru bangun tidur ada 7 orang, setelah sarapan ada 3 orang, saat buang air besar ada 2 orang, saat jam istirahat pelajaran sekolah ada 10 orang, setelah makan siang ada 15 orang, setelah makan malam ada 17 orang, dan menjelang tidur malam ada 30 orang.

Berdasarkan intensitas merokok, siswa laki-laki SMA Negeri 1 Semarapura yang merokok 1-4 batang per hari ada 21 orang, 4-15 batang per hari ada 37 orang, dan lebih dari 15 batang per hari ada 5 orang.

Dari sana, dapat ditarik gambaran bahwa rata-rata siswa laki-laki SMA Negeri 1 Semarapura merokok untuk mengurangi perasaan cemas, marah dan gelisah berdasarkan fungsi merokok, merokok di kamar pribadi berdasarkan tempat merokok, merokok menjelang tidur malam berdasarkan waktu merokok, dan merokok 4-15 batang sehari berdasarkan intensitas merokok.

Hasil kategorisasi deksriptif menunjukkan bahwa kebanyakan siswa laki-laki SMA Negeri 1 Semarapura merokok dengan tujuan mengurangi perasaan cemas, marah, dan gelisah terkait dengan adanya perasaan tertekan yang timbul dari perjuangan mencari identitas diri sehingga akhirnya memilih perilaku merokok untuk meredakan stres (Schultz \& Schultz, 1987). Apalagi, bagi sebagian besar perokok, sudah tertanam pola pikir bahwa merokok dapat melenyapkan stres (Parrott, 1999). Kebanyakan siswa SMA Negeri 1 Semarapura merokok di dalam kamar pribadi karena pada usia remaja, terdapat kebutuhan akan privasi sebagai salah satu hal yang menunjang identitas diri (Schultz \& Schultz, 1987). Selain itu, dengan merokok di dalam kamar pribadi, kemungkinan untuk diketahui oleh guru dan orang tua akan lebih kecil mengingat remaja masih cukup memandang pujian dan larangan yang diterapkan guru dan orang tua (Atkinson, Atkinson, \& Hilgard, 1983). Kebanyakan siswa SMA Negeri 1 Semarapura merokok menjelang tidur malam karena menurut Susanto (2013), remaja cenderung mengalami masa-masa tidak nyaman secara mental dan emosional sebelum tidur, karena malam hari sebelum tidur remaja tidak beraktivitas apa-apa dan pikirannya dalam keadaan rileks sehingga mudah terpicu untuk memikirkan masalahnya. Agar tidak stres dan memiliki aktivitas untuk dikerjakan, remaja akhirnya memilih untuk merokok. Kebanyakan siswa SMA Negeri 1 Semarapura merokok 4-15 batang per hari terkait dengan fenomena di mana remaja sekarang ini memperoleh uang jajan berlebih yang jumlahnya cukup banyak untuk membeli rokok satu bungkus dan sering menjadikan merokok sebagai perilaku sosial, yang mana remaja ketika berkumpul dengan teman-temannya akan merokok tanpa ingat jumlah sehingga mendorong remaja untuk terus merokok (Susanto, 2013).

Terkait dengan apa yang dikemukakan, ibu yang mendidik anak dengan tipe pola asuh permisif dapat mencoba untuk meningkatkan kontrol pada perilaku anak khususnya pada perilaku anak yang berdampak negatif, seperti merokok. Hal ini sebaiknya dilakukan mengingat kurangnya kontrol pada perilaku negatif anak dapat merugikan anak. Kurangnya kontrol dapat membuat anak terlanjur terkena dampak dari perilaku negatifnya sebab sebelumnya ibu tidak pernah mencoba menghentikan atau menegur perilakunya. Dengan begitu, ibu dapat membimbing anak dalam berperilaku sesuai dengan norma dan aturan yang berlaku tanpa menghilangkan unsur kehangatan dalam keluarga. Suasana komunikatif yang dibentuk dalam keluarga juga membuat anak lebih nyaman dalam mengkomunikasikan masalahnya, sehingga ibu dapat memantau permasalahan anak dan mencegah anak memilih strategi koping maladaptif seperti merokok tanpa membuat anak merasa dikekang (Idris \& Jamal,1992). Jika anak masih terus melakukan perilaku merokok, ibu disarankan tidak membiarkan begitu saja dan memberikan teguran. Sikap diam ibu dianggap sebagai persetujuan merokok oleh anak dan hukuman dalam bentuk teguran dibutuhkan untuk mengingatkan anak bahwa perilaku merokok bukanlah perilaku yang disetujui. Selain itu, hasil kategorisasi yang dilakukan menunjukkan bahwa rata-rata fungsi merokok pada anak adalah untuk mengurangi perasaan negatif yang dialami. Dengan memberi bimbingan pada anak, anak akan dapat menemukan cara yang lebih baik untuk mengurangi perasaan negatif yang dialaminya karena merasa didukung dan dibimbing sehingga tidak melampiaskan emosinya dengan cara merokok. Dan sebaiknya, mengingat anak dapat membeli rokok karena memiliki uang jajan berlebih, ibu sebaiknya mengontrol uang jajan anak sesuai dengan kebutuhan anak dan tidak berlebihan.

Selain itu, bagi anak, disarankan untuk menghadapi problem yang timbul dari upaya mencari identitas diri seperti perilaku merokok dengan jalan meminta bimbingan dari orang tua. Anak dapat bersikap asertif mengenai kesulitan dan masalah yang ditemui termasuk masalah merokok ini pada orang tua, mengingat orang tua khususnya ibu adalah figur kelekatan utama yang diharapkan dapat memberikan bimbingan dalam berperilaku. Jika lingkungan pergaulan menekan anak untuk merokok, maka anak sebaiknya bersikap 
asertif dengan menolak daripada memaksakan diri merokok mengingat dampak negatif yang ditimbulkan perilaku merokok. Asertifitas ditekankan karena perilaku asertif dapat mengurangi stres dan konflik yang dirasakan sehingga tidak sampai merasa perlu melarikan diri ke hal-hal negatif seperti merokok (Alberti \& Emmons, dalam Marini \& Andriani, 2005). Apabila anak merokok untuk mengurangi perasaan negatif, maka anak harus mengingat bahwa merokok tidak menyelesaikan masalah dan efek lega yang timbul dari merokok hanyalah sugesti semata (Parrott, 1999). Apabila anak merokok di malam hari karena tidak ada aktivitas dan untuk menghindari stres, disarankan bagi anak untuk mencari aktivitas lain yang tidak berdampak negatif bagi kesehatan seperti menonton televisi, mendengar musik, atau mengobrol dengan orang tua.

Kepada peneliti selanjutnya, disarankan untuk melihat variabel atau faktor lain yang terkait dengan perilaku merokok pada remaja agar dapat memperkaya literatur mengenai perilaku merokok pada remaja sendiri, mengingat kontribusi variabel pola asuh permisif dan perilaku merokok pada remaja hanya sebatas $24,3 \%$ sementara sisanya ditentukan variabel lain. Dengan demikian, akan diperoleh gambaran yang menyeluruh mengenai perilaku merokok pada remaja sehingga memudahkan intervensi terhadap perilaku merokok remaja.

Dari segi metodologi penelitian, disarankan untuk melakukan wawancara dan observasi untuk memperoleh data yang lebih mendalam, mengingat dalam penelitian ini wawancara dan observasi tidak dilakukan karena keterbatasan waktu dan sumber daya yang dimiliki oleh peneliti.

\section{DAFTAR PUSTAKA}

Amelia A. (2009). Gambaran Perilaku Merokok pada Laki-laki. Skripsi yang tidak diterbitkan, Fakultas Psikologi Universitas Sumatera Utara.

Atkinson RL, Atkinson RC, Hilgard ER. (1983). Pengantar Psikologi 1. Jakarta: Penerbit Erlangga.

Baumrind D. (1966). Effects of authoritative parental control on child behavior. Child Development, 37, 887-907.

Boediono dan Koster W. (2004). Teori dan Aplikasi Statistika dan Probabilitas. Bandung: PT Remaja Rosdakarya.

Eliasa EI. (2011). Karakter Sebagai Saripati Tumbuh Kembang Anak Usia Dini. Yogyakarta: Inti Media Yogyakarta.

Fagan. (2006). Psikologi Remaja. Jakarta: PT Gramedia Pustaka.

Fraenkel RJ dan Wallen NE. (1993). How to design and evaluate research in education. New York: McGraw-Hill

Ghozali I. (2002). Aplikasi Analisis Multivariate Dengan Program SPSS. Semarang: Badan Penerbit Universitas Diponegoro.

Hasnida dan Kemala I. (2005). Hubungan Antara Stres dan Perilaku Merokok pada Remaja Laki-Laki. Psikologia, 1 (2), 105-111.
Huver R, Otten R, Vries HD, dan Engels R. (2010). Personality and Parenting Style in Parents of Adolescents. Journal of Adolescence, 33, 395-402.

Hurlock EB. (1976). Personality Development. New York: McGrawHill Education.

Idris Z dan Jamal L. (1992). Pengantar Pendidikan. Jakarta: Gramedia Widiasarana.

Karyadi. (2008). Hubungan Pola Asuh Keluarga Terhadap Perilaku Merokok pada Remaja Laki-laki di Desa Kenteng Kecamatan Nogosari Kabupaten Boyolali Tahun 2007. Skripsi yang tidak diterbitkan, Fakultas Ilmu Kesehatan Universitas Muhammadiyah Surakarta.

Komalasari D dan Helmi AF. (2000). Faktor-faktor Penyebab Perilaku Merokok pada Remaja. Jurnal Psikologi Universitas Gadjah Mada, 2, 1-11.

Kompas. (2013). Perilaku Merokok Pelajar di Jakarta Mengkhawatirkan. Damanik C (editor). http://edukasi.kompas.com/read/2013/03/27/10293524/Perilaku. Merokok.Pelajar.di.Jakarta.Mengkhawatirkan?utm_source=WP danutm_medium=boxdanutm_campaign $=$ Kknwp [diunduh pada tanggal 29 Maret 2013]

Lombardi KS. (2012). The Mama's Boy Myth: Why Keeping Our Sons Close Makes Them Stronger. Penguin Group: USA.

Marini L dan Andriani E. (2005). Perbedaan Asertifitas Remaja Ditinjau dari Pola Asuh Orang Tua. Psikologia, 1, 46-53.

Murtiyani N. (2011). Hubungan Pola Asuh Orang Tua dengan Kenakalan Remaja di RW V Kelurahan Sidokare Kecamatan Sidoarjo. Jurnal Keperawatan, 1 (1), 1-9.

Nasution IK. (2007). Perilaku Merokok pada Remaja. Medan: Universitas Sumatera Utara.

Nunnaly JC. (1978). Psychometric Theory. New York: McGraw-Hill. Parrott AC. (1999) Does Cigarette Smoking Cause Stress?. American Psychologist 54, 817.

Paterson J. (1993). Adolescent perceptions of attachment: parents, friends, and impact on self esteem. Tesis, Department of Psychology. University of Auckland.

Rohman A. (2012). Hubungan Antara Tingkat Stres dan Status Sosial Ekonomi Orang Tua dengan Perilaku Merokok pada Remaja. http://psikologi.or.id [diunduh pada tanggal 26 Februari 2012]

Rosenthal NL dan Kobak R. (2010). Assessing Adolescents' Attachment Hierarchies: Differences Across Developmental Periods and Associations With Individual Adaptation. Journal of Research on Adolescence, 1-29.

Schultz DP dan Schultz S.E. (1987). A History of Modern Psychology. Florida: Harcourt-Brace.

Sitepoe M. (2005). Kekhususan Rokok Indonesia. Jakarta : Gramedia Medika Sarana Indonesia.

Smet B. (1994). Psikologi Kesehatan. Jakarta: Gramedia Widiasarana Indonesia.

Sugiyono. (2007). Metode Penelitian Kuantitatif Kualitatif dan $R \&$ D. Bandung: CV. Alfabeta

Sugiyono. (2011). Statistika untuk Penelitian. Bandung: CV. Alfabeta.

Susanto A. (2013). Merokok? So last year. http://www.blogger.com. [diunduh pada tanggal 26 September 2013]

Taylor SE, Peplau LA, dan Sears DO. (2009). Psikologi Sosial (12th ed.). Jakarta: Kencana Prenada Media Grup. 